Article

\title{
Kinetic Modification on Hydrogen Desorption of Lithium Hydride and Magnesium Amide System
}

\section{Hiroki Miyaoka ${ }^{1, *}$, Yongming Wang ${ }^{2}$, Satoshi Hino ${ }^{2}$, Shigehito Isobe ${ }^{2}$, Kazuhiko Tokoyoda ${ }^{3}$, Takayuki Ichikawa ${ }^{4}$ and Yoshitsugu Kojima 5}

1 Institute for Sustainable Sciences and Development, Hiroshima University, 1-3-1 Kagamiyama, Higashi-Hiroshima 739-8530, Japan

2 Creative Research Institution, Hokkaido University, N-21, W-10, Sapporo 001-0021, Japan; E-Mails: wang@eng.hokudai.ac.jp (Y.W.); s.hino@eng.hokudai.ac.jp (S.H.); isobe@eng.hokudai.ac.jp (S.I.)

3 Central Research Laboratory, Taiheiyo Cement Corporation, 2-4-2 Osaku, Sakura 285-8655, Japan; E-Mail: Kazuhiko_Tokoyoda@taiheiyo-cement.co.jp

4 Graduate School of Integrated Arts and Sciences, Hiroshima University, 1-7-1 Kagamiyama, Higashi-Hiroshima 739-8521, Japan; E-Mail: tichi@hiroshima-u.ac.jp

5 Institute for Advanced Materials Research, Hiroshima University, 1-3-1 Kagamiyama, Higashi-Hiroshima 739-8530, Japan; E-Mail: kojimay@hiroshima-u.ac.jp

* Author to whom correspondence should be addressed; E-Mail: miyaoka@h2.hiroshima-u.ac.jp; Tel.: +81-82-424-4604.

Academic Editor: Umit Demirci

Received: 25 April 2015 / Accepted: 9 June 2015 / Published: 29 June 2015

\begin{abstract}
Various synthesis and rehydrogenation processes of lithium hydride ( $\mathrm{LiH})$ and magnesium amide $\left(\mathrm{Mg}\left(\mathrm{NH}_{2}\right)_{2}\right)$ system with 8:3 molar ratio are investigated to understand the kinetic factors and effectively utilize the essential hydrogen desorption properties. For the hydrogen desorption with a solid-solid reaction, it is expected that the kinetic properties become worse by the sintering and phase separation. In fact, it is experimentally found that the low crystalline size and the close contact of $\mathrm{LiH}$ and $\mathrm{Mg}\left(\mathrm{NH}_{2}\right)_{2}$ lead to the fast hydrogen desorption. To preserve the potential hydrogen desorption properties, thermochemical and mechanochemical rehydrogenation processes are investigated. Although the only thermochemical process results in slowing the reaction rate due to the crystallization, the ball-milling can recover the original hydrogen desorption properties. Furthermore, the mechanochemical process at $150{ }^{\circ} \mathrm{C}$ is useful as the rehydrogenation technique to
\end{abstract}


preserve the suitable crystalline size and mixing state of the reactants. As a result, it is demonstrated that the $8 \mathrm{LiH}$ and $3 \mathrm{Mg}\left(\mathrm{NH}_{2}\right)_{2}$ system is recognized as the potential hydrogen storage material to desorb more than 5.5 mass $\%$ of $\mathrm{H}_{2}$ at $150{ }^{\circ} \mathrm{C}$.

Keyword: hydrogen storage; kinetics; crystallinity; ball-milling; mechanochemical process; lithium; magnesium

\section{Introduction}

Hydrogen $\left(\mathrm{H}_{2}\right)$ is an attractive energy carrier to effectively utilize natural energy resources such as solar, hydro, and wind energy. However, it is difficult to produce the high condensation state because $\mathrm{H}_{2}$ is in the gaseous phase under ambient conditions and the critical point is $-240{ }^{\circ} \mathrm{C}$. Thus, hydrogen storage techniques are necessary to compactly store and transport hydrogen and have been investigated. Hydrogen storage in materials is one of attractive techniques because they can store hydrogen as atomic state, resulting in the highly compact state. In 2007, a target of hydrogen storage materials for fuel cell vehicle is determined by New Energy and Industrial Technology Development Organization (NEDO) in Japan [1]. In this policy, more than 5.5 mass \% of the reversible hydrogen capacity and less than $150{ }^{\circ} \mathrm{C}$ for the operating temperature are required, where these values are based on material. To achieve the above targets, the hydrogen storage materials based on light elements, lithium (Li), sodium (Na), magnesium $(\mathrm{Mg})$, boron $(\mathrm{B})$, carbon $(\mathrm{C})$, and nitrogen $(\mathrm{N})$, attract much interest because these materials can realize the high gravimetric hydrogen density, which is potentially higher than the target value [2-11]. Among them, the amide-imide system is recognized as an attractive hydrogen storage system. The reaction of typical Li system is described as follows [12]:

$$
\mathrm{LiH}+\mathrm{LiNH}_{2} \leftrightarrow \mathrm{Li}_{2} \mathrm{NH}+\mathrm{H}_{2}
$$

in this system, lithium amide $\left(\mathrm{LiNH}_{2}\right)$ phase in the hydrogenated state is changed to imide phase $\left(\mathrm{Li}_{2} \mathrm{NH}\right)$ after the hydrogen desorption. Although about 6.0 mass $\%$ of hydrogen is reversibly stored, the hydrogen desorption requires more than $200{ }^{\circ} \mathrm{C}$ due to the high enthalpy change, $\Delta H=67 \mathrm{~kJ} \cdot \mathrm{mol}^{-1} \mathrm{H}_{2}$ [13-15]. To decrease the reaction temperature, the lithium hydride $(\mathrm{LiH})$ and magnesium amide $\left(\mathrm{Mg}\left(\mathrm{NH}_{2}\right)_{2}\right)$ system has been proposed. Systems with different molar ratio were reported at almost the same time by Luo et al. [16], Leng et al. [17], Xiong et al. [18], and Nakamori et al. [19]. The representative three reactions are described as follows:

$$
\begin{gathered}
6 \mathrm{LiH}+3 \mathrm{Mg}\left(\mathrm{NH}_{2}\right)_{2} \rightarrow 3 \mathrm{Li}_{2} \mathrm{Mg}(\mathrm{NH})_{2}+6 \mathrm{H}_{2}(5.5 \text { mass\% }) \\
8 \mathrm{LiH}+3 \mathrm{Mg}\left(\mathrm{NH}_{2}\right)_{2} \rightarrow 4 \mathrm{Li}_{2} \mathrm{NH}+\mathrm{Mg}_{3} \mathrm{~N}_{2}+8 \mathrm{H}_{2}(6.9 \text { mass} \%) \\
12 \mathrm{LiH}+3 \mathrm{Mg}\left(\mathrm{NH}_{2}\right)_{2} \rightarrow 4 \mathrm{Li}_{3} \mathrm{~N}+\mathrm{Mg}_{3} \mathrm{~N}_{2}+12 \mathrm{H}_{2}(9.1 \text { mass\%) }
\end{gathered}
$$

the detailed reaction process of the $8 \mathrm{LiH}-3 \mathrm{Mg}\left(\mathrm{NH}_{2}\right)_{2}$ system below $200{ }^{\circ} \mathrm{C}$ is expressed as follows [20]:

$$
\begin{gathered}
8 \mathrm{LiH}+3 \mathrm{Mg}\left(\mathrm{NH}_{2}\right)_{2} \rightarrow 3 \mathrm{LiMgN}_{2} \mathrm{H}_{3}+5 \mathrm{LiH}+3 \mathrm{H}_{2} \\
8 \mathrm{LiH}+3 \mathrm{Mg}\left(\mathrm{NH}_{2}\right)_{2} \rightarrow 3 \mathrm{Li}_{1+}{ }_{x} \mathrm{MgN}_{2} \mathrm{H}_{3-x}+(5-3 x) \mathrm{LiH}+(3+3 x) \mathrm{H}_{2} \\
8 \mathrm{LiH}+3 \mathrm{Mg}\left(\mathrm{NH}_{2}\right)_{2} \rightarrow 3 \mathrm{Li}_{2.7} \mathrm{MgN}_{2} \mathrm{H}_{1.3}+8 \mathrm{H}_{2}
\end{gathered}
$$


where $x: 0<x<1.7$. First, $3 \mathrm{~mol}$ of $\mathrm{H}_{2}$ is desorbed by Equation (5) with the flat plateau in the pressure-composition isotherm (PCI) [21]. After that, $3 \mathrm{LiMgN}_{2} \mathrm{H}_{3}\left(=3 \mathrm{LiNH}_{2}-3 \mathrm{MgNH}\right)$ continuously reacts with $\mathrm{LiH}$ and desorbs $\mathrm{H}_{2}$. The compositions of $\mathrm{Li}$ and $\mathrm{H}$ in the product defined as $\mathrm{Li}_{1+x} \mathrm{MgN}_{2} \mathrm{H}_{3-x}$ are non-stoichiometrically varied in this process, resulting in the slope in the PCI [21,22]. Under vacuum condition at $200{ }^{\circ} \mathrm{C}$, a single phase of $3 \mathrm{Li}_{2.7} \mathrm{MgN}_{2} \mathrm{H}_{1.3}\left(=4 \mathrm{Li}_{2} \mathrm{NH}-\mathrm{Mg}_{3} \mathrm{~N}_{2}\right)$ is finally formed, and then total 6.9 mass $\%$ of hydrogen can be desorbed [23], where this single phase would disproportionate into $\mathrm{Li}_{2} \mathrm{NH}$ and $\mathrm{Mg}_{3} \mathrm{~N}_{2}$ under higher temperature condition [17]. Thus, this system is recognized as a potential hydrogen storage material to achieve the above practical properties. However, improvement of the hydrogen storage properties is still necessary. The cyclic hydrogen absorption and desorption properties were investigated by Ikeda et al. [24]. They reported that the initial hydrogen desorption capacity was 4.6 mass $\%$ and decayed to 3.6 mass $\%$ after 300 cycles at $200{ }^{\circ} \mathrm{C}$. They claimed that the $\mathrm{NH}_{3}$ emission during the dehydrogenation is the origin of decrease in the hydrogen capacity. On the other hand, the detailed properties at $150{ }^{\circ} \mathrm{C}$, as the target temperature, have not been clarified yet. At lower temperatures, the kinetic control would be main issue to utilize the essential hydrogen storage properties because hydrogen is desorbed by the solid-solid reaction and the hydrogen absorption proceeds with the phase separation. Namely, the crystalline size of solid materials and the contact between two solid phases would be important factors to realize suitable reaction rate at $150{ }^{\circ} \mathrm{C}$. Furthermore, it is expected that the sintering and/or crystallization of solid materials by heating for the hydrogen desorption and absorption processes slows the reaction rates.

In this work, the various synthesis and rehydrogenation processes of the $8 \mathrm{LiH}-3 \mathrm{Mg}\left(\mathrm{NH}_{2}\right)_{2}$ system are investigated to understand the essential hydrogen storage properties as fundamental research. From the obtained experimental results, the feasibility of achieving 5.5 mass $\% \mathrm{H}_{2}$ desorption at $150{ }^{\circ} \mathrm{C}$ is discussed.

\section{Results and Discussion}

Figure 1 shows X-ray diffraction (XRD) patterns of the pristine and ball-milled LiH with the patterns of $\mathrm{LiH}$ and $\mathrm{Li}_{2} \mathrm{O}$ in database as reference. Here, broad peaks around $20^{\circ}$ and $25^{\circ}$ are caused by a grease to spread the powder sample and a polyimide sheet to cover the sample for avoiding the oxidation.

The diffraction peaks observed in the case of pristine LiH were high intensity and sharp. After the ball-milling as pre-treatment, the peaks were clearly lowered and broadened, suggesting that the crystalline size was reduced and the structural disorder was induced. The milling effects became slightly strong for $34 \mathrm{~h}$.

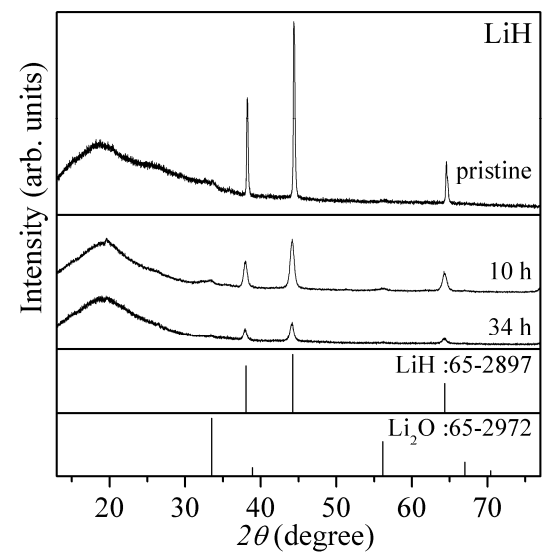

Figure 1. XRD (X-ray diffraction) patterns of the pristine and ball-milled $\mathrm{LiH}(10 \mathrm{~h}$ and $34 \mathrm{~h})$. XRD patterns of $\mathrm{LiH}$ and $\mathrm{Li}_{2} \mathrm{O}$ in database are also shown as reference. 
$\mathrm{Mg}\left(\mathrm{NH}_{2}\right)_{2}$ used in this work was synthesized by the method reported before [15,25]. $\mathrm{Mg}\left(\mathrm{NH}_{2}\right)_{2}$ and $10 \mathrm{~h}$ milled LiH were mixed with a 3:8 molar ratio by ball-milling for 2 and $20 \mathrm{~h}$, and the property of each mixture was compared with the samples synthesized from the pristine $\mathrm{LiH}$ (see also Figure S1). Figure 2a shows XRD patterns of 2 and $20 \mathrm{~h}$ milled mixtures using the pristine and pretreated $\mathrm{LiH}$ (10 h milled). The only LiH phase was observed without impurity phases such as oxides and the peak intensity and shape were almost similar for all the samples. $\mathrm{Mg}\left(\mathrm{NH}_{2}\right)_{2}$ should be of nano-structure or amorphous, as no diffraction peaks appeared. From the XRD results, clear difference was not found. On the other hand, the hydrogen desorption profiles obtained by thermogravimetry-mass spectroscopy (TG-MS) showed the different behaviors as shown in Figure 2b. Here, the hydrogen desorption as shoulder around $250-300{ }^{\circ} \mathrm{C}$ would be caused by the variation of reaction path from Equations (3) to (6) with the phase separation [17]. The hydrogen desorption peaks corresponding to the samples milled for $2 \mathrm{~h}$ were slightly broad and weak compared with those of the sample milled for $20 \mathrm{~h}$. Moreover, the weight loss corresponding to the $20 \mathrm{~h}$ milled sample was closer to the theoretical value, 6.9 mass $\%$. As described above, it is known that the small amount of $\mathrm{NH}_{3}$ originated in the decomposition of $\mathrm{Mg}\left(\mathrm{NH}_{2}\right)_{2}$ is released with the $\mathrm{H}_{2}$ desorption. When the mixing state between $\mathrm{LiH}$ and $\mathrm{Mg}\left(\mathrm{NH}_{2}\right)_{2}$ is poor, the $\mathrm{NH}_{3}$ desorption amount should be increased. Thus, these results indicate that the mixing state between two solid phases started by the pre-treated $\mathrm{LiH}$ was much better in the $2 \mathrm{~h}$ milled mixtures. However, for the $20 \mathrm{~h}$ milled mixtures, the hydrogen desorption profile was clearly sharpened, suggesting that the two materials with the better mixing state easily reacted. In this case, the effect of pre-treatment was not clear because of the same TG-MS profiles in our experimental accuracy. It is expected that the crystalline size of LiH is reduced enough to form the good contact between $\mathrm{LiH}$ and $\mathrm{Mg}\left(\mathrm{NH}_{2}\right)_{2}$ during the $20 \mathrm{~h}$ milling. The weight loss corresponding to the hydrogen desorption was almost consistent with the theoretical value due to the faster reaction rate. Although it is clarified that the pre-treatment of $\mathrm{LiH}$ is effective to improve the kinetics of hydrogen desorption, it is not necessary when the mixing time is long enough.
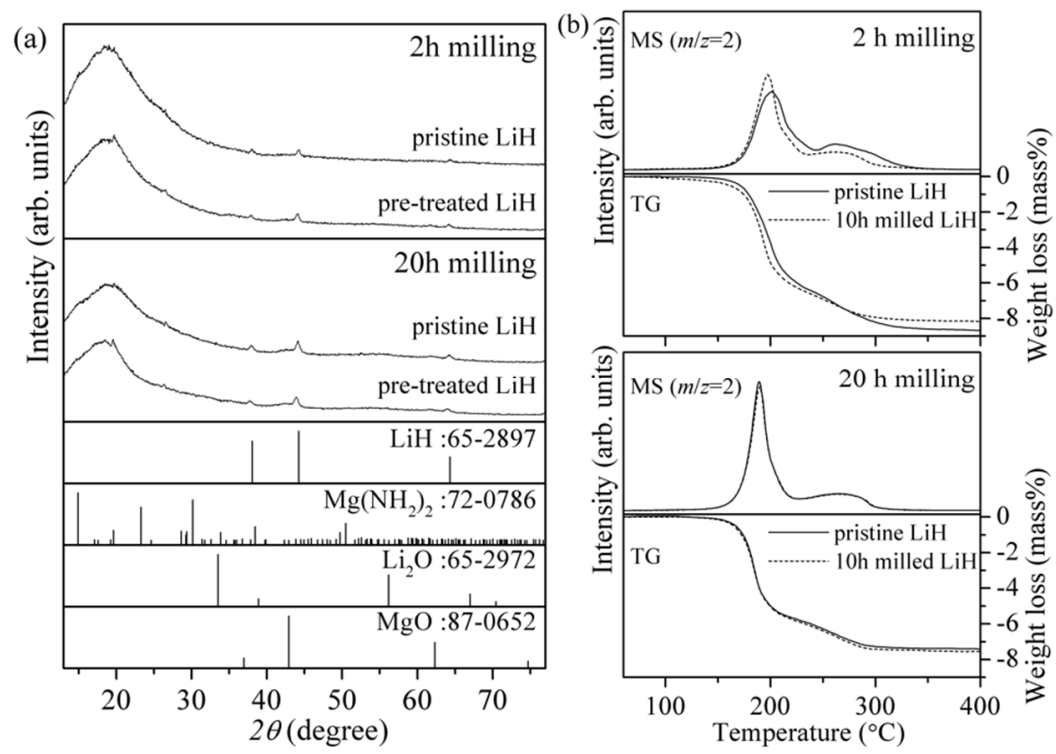

Figure 2. (a) XRD patterns and (b) TG-MS (thermogravimetry-mass spectroscopy) profiles of the $8 \mathrm{LiH}-3 \mathrm{Mg}\left(\mathrm{NH}_{2}\right)_{2}$ samples synthesized from the pristine or pre-treated $\mathrm{LiH}$ (10 h milling) by ball-milling for $2 \mathrm{~h}$ and $20 \mathrm{~h}$. XRD patterns of $\mathrm{LiH}, \mathrm{Mg}\left(\mathrm{NH}_{2}\right)_{2}, \mathrm{Li}_{2} \mathrm{O}$, and $\mathrm{MgO}$ in database are shown as reference. 
In order to examine an effect of the longer mixing time of $\mathrm{LiH}$ and $\mathrm{Mg}\left(\mathrm{NH}_{2}\right)_{2}$, the sample was prepared by milling for $40 \mathrm{~h}$. In Figure 3a, the TG-MS results are compared, in which LiH used here was not pre-treated. The reaction rate of the $20 \mathrm{~h}$ milled sample was obviously faster than that of the $2 \mathrm{~h}$ milled sample. However, no clear difference between the samples prepared by the $20 \mathrm{~h}$ and $40 \mathrm{~h}$ milling was found in the TG-MS profiles, indicating that the reduction of crystalline size was saturated and the close contact of two materials was realized by milling for $20 \mathrm{~h}$.

Figure $3 \mathrm{~b}$ shows isothermal TG profiles of the 2 and $20 \mathrm{~h}$ milled $8 \mathrm{LiH}-3 \mathrm{Mg}\left(\mathrm{NH}_{2}\right)_{2}$ samples at $150{ }^{\circ} \mathrm{C}$ for $8 \mathrm{~h}$. For the $2 \mathrm{~h}$ milled sample, the weight loss due to the hydrogen desorption gradually proceeded and the hydrogen desorption amount was less than 5.0 mass \%, even after $8 \mathrm{~h}$. On the other hand, the $20 \mathrm{~h}$ milled sample revealed faster reaction rate, and then the hydrogen desorption amount reached to about 6.0 mass \% within $3 \mathrm{~h}$. To accurately evaluate the potential amount of hydrogen desorption, the $\mathrm{NH}_{3}$ emission should be considered. In previous reports, about $0.05 \mathrm{~mol} \%$ of $\mathrm{NH}_{3}$ was essentially released during all the hydrogen absorption and desorption cycles at $200{ }^{\circ} \mathrm{C}$ [24]. In fact, the small amount of $\mathrm{NH}_{3}$ was also observed in MS measurement around $200{ }^{\circ} \mathrm{C}$ [26]. On the other hand, the MS signal corresponding to $\mathrm{NH}_{3}$ was quite low intensity and out of an apparatus resolution at $150{ }^{\circ} \mathrm{C}$. Therefore, the contribution of $\mathrm{NH}_{3}$ emission to the weight loss in the isothermal TG measurement at $150{ }^{\circ} \mathrm{C}$ performed in this work was negligible.
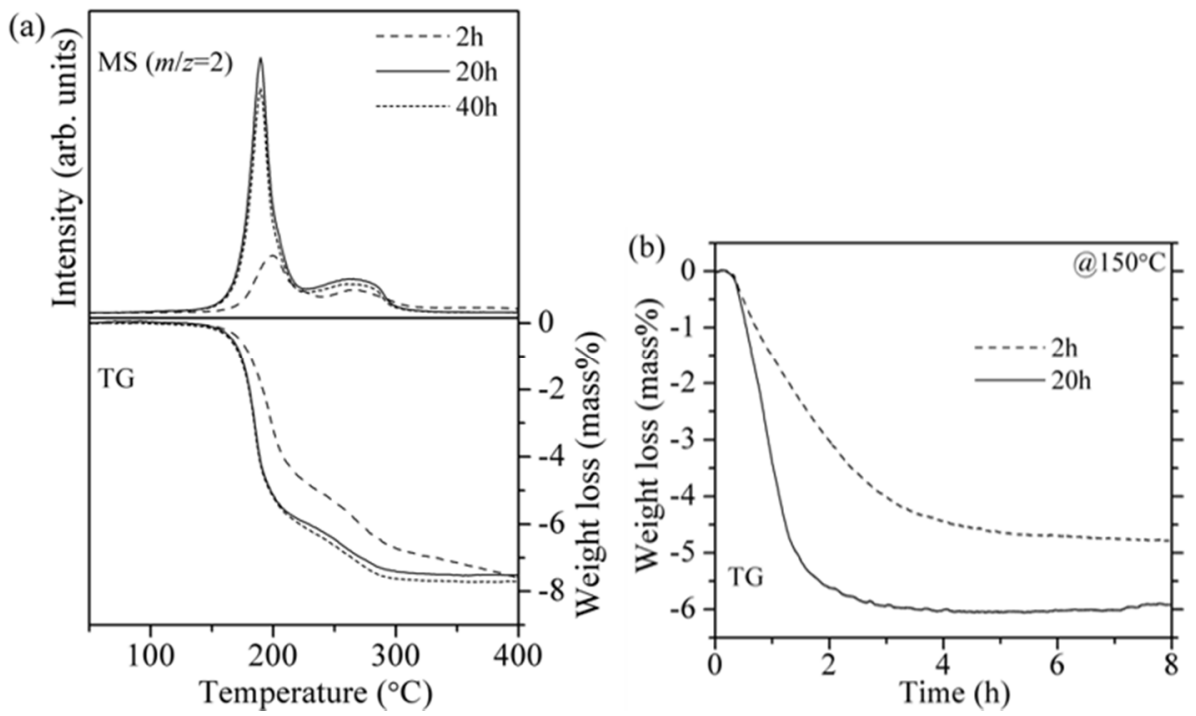

Figure 3. (a) TG-MS profiles of the $8 \mathrm{LiH}-3 \mathrm{Mg}\left(\mathrm{NH}_{2}\right)_{2}$ samples synthesized by ball-milling for 2, 20, and $40 \mathrm{~h}$; (b) Isothermal TG profiles at $150{ }^{\circ} \mathrm{C}$ of the $2 \mathrm{~h}$ and $20 \mathrm{~h}$ milled samples.

For the $\mathrm{LiH}-\mathrm{LiNH}_{2}$ system, $1 \mathrm{~mol} \%$ titanium chloride $\left(\mathrm{TiCl}_{3}\right)$ shows excellent catalytic effect and lowers the peak temperature of hydrogen desorption in the MS analysis [27,28]. On the basis of previous works, the effects of $\mathrm{TiCl}_{3}$ on the $8 \mathrm{LiH}-3 \mathrm{Mg}\left(\mathrm{NH}_{2}\right)_{2}$ system was investigated. Figure 4 shows the results of TG-MS measurement for the $8 \mathrm{LiH}-3 \mathrm{Mg}\left(\mathrm{NH}_{2}\right)_{2}$ samples with and without $\mathrm{TiCl}_{3}$. The peak temperature of hydrogen desorption was located around $190{ }^{\circ} \mathrm{C}$ for both samples, and the profiles were almost same. The TG profiles were also similar, where the slight difference of weight loss at $400{ }^{\circ} \mathrm{C}$ would be caused by the $\mathrm{TiCl}_{3}$ addition. Thus, it was clarified that $\mathrm{TiCl}_{3}$ has no significant catalytic effects on the $8 \mathrm{LiH}-3 \mathrm{Mg}\left(\mathrm{NH}_{2}\right)_{2}$ system, suggesting that the reaction processes are possibly different from the $\mathrm{LiH}$ and $\mathrm{LiNH}_{2}$ system. 


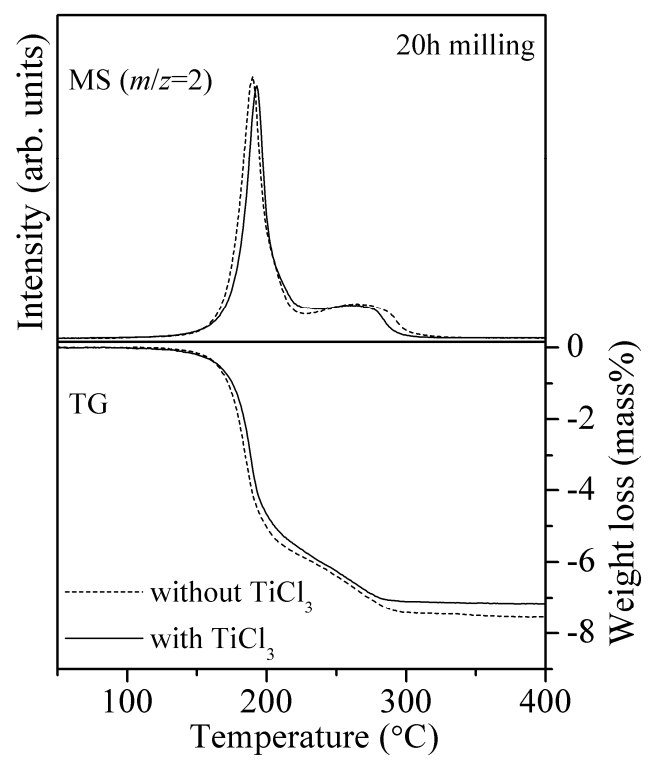

Figure 4. TG-MS profiles of the $8 \mathrm{LiH}-3 \mathrm{Mg}\left(\mathrm{NH}_{2}\right)_{2}$ samples with and without $0.54 \mathrm{~mol} \%$ $\mathrm{TiCl}_{3}$ synthesized by the ball-milling for $20 \mathrm{~h}$.

From the above results, the $8 \mathrm{LiH}-3 \mathrm{Mg}\left(\mathrm{NH}_{2}\right)_{2}$ sample synthesized from the pristine $\mathrm{LiH}$ by ball-milling for $20 \mathrm{~h}$ is chosen as the starting material for experiments to investigate the rehydrogenation processes. The synthesized $8 \mathrm{LiH}-3 \mathrm{Mg}\left(\mathrm{NH}_{2}\right)_{2}$ was dehydrogenated at $200{ }^{\circ} \mathrm{C}$ under dynamic vacuum condition for $24 \mathrm{~h}$. The dehydrogenated sample was analyzed by the TG-MS measurement to quantitatively evaluate the progress of reaction. As a result, the weight loss with heating up to $400{ }^{\circ} \mathrm{C}$ was less than 0.5 mass\% (see Figure S2), suggesting that the dehydrogenation was almost completed in this condition. The rehydrogenation was performed at $200{ }^{\circ} \mathrm{C}$ under $10.0 \mathrm{MPa}$ of $\mathrm{H}_{2}$ for $12 \mathrm{~h}$. After the thermochemical rehydrogenation, it is expected that the crystallization and sintering of the solid particles are induced. To reduce the crystalline size and recover the close contact between $\mathrm{LiH}$ and $\mathrm{Mg}\left(\mathrm{NH}_{2}\right)_{2}$, the rehydrogenated sample was ball-milled under three different temperature conditions, at room temperature, $100{ }^{\circ} \mathrm{C}$, and $-79^{\circ} \mathrm{C}$, where the products were named "rehy + mill". Here, the results of sample prepared at room temperature is omitted in the discussion below because the properties are almost same as those prepared at $100{ }^{\circ} \mathrm{C}$ and $-79{ }^{\circ} \mathrm{C}$. Figure 5 representatively shows the TG-MS profiles of the rehy+ mill@ $100{ }^{\circ} \mathrm{C}$ and rehy + mill@ $-79{ }^{\circ} \mathrm{C}$ samples with the profiles of the samples after synthesis and thermochemical rehydrogenation. In addition, all the information obtained by TG-MS measurements is listed in Table 1. 


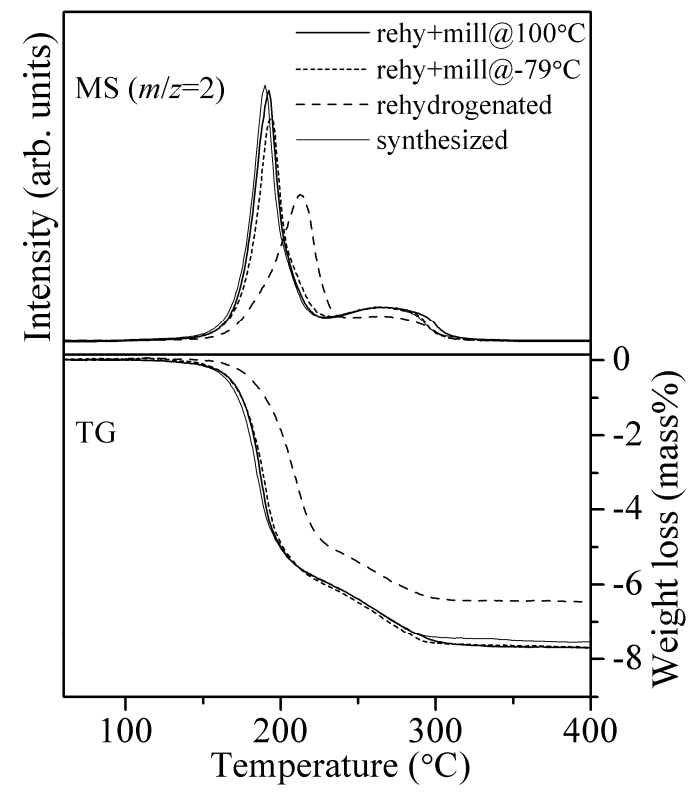

Figure 5. TG-MS profiles of the $8 \mathrm{LiH}-3 \mathrm{Mg}\left(\mathrm{NH}_{2}\right)_{2}$ samples after the synthesis, the thermochemical rehydrogenation, and the ball-milling at $100{ }^{\circ} \mathrm{C}$ and $-79{ }^{\circ} \mathrm{C}$ for the rehydrogenated sample.

Table 1. Peak temperature and weight loss obtained by TG-MS to $400{ }^{\circ} \mathrm{C}$, weight loss obtained by isothermal TG measurements at $150{ }^{\circ} \mathrm{C}$ for $8 \mathrm{~h}$, and time required to desorb 5.5 mass $\%$ of hydrogen at $150{ }^{\circ} \mathrm{C}$ of each sample.

\begin{tabular}{|c|c|c|c|c|}
\hline \multirow[b]{2}{*}{ Sample } & \multicolumn{2}{|c|}{ TG-MS (to $400{ }^{\circ} \mathrm{C}$ ) } & \multicolumn{2}{|c|}{ Isothermal TG $\left(150{ }^{\circ} \mathrm{C}, 8 \mathrm{~h}\right)$} \\
\hline & $\begin{array}{c}\text { Peak temperature } \\
\left({ }^{\circ} \mathrm{C}\right)\end{array}$ & $\begin{array}{l}\text { Weight loss } \\
\text { (mass\%) }\end{array}$ & $\begin{array}{l}\text { Weight loss } \\
\text { (mass\%) }\end{array}$ & $\begin{array}{c}\text { Time to } 5.5 \text { mass } \% \\
\text { (h) }\end{array}$ \\
\hline Synthesized & 190 & 7.5 & 6.0 & 1.8 \\
\hline Rehydrogenated & 213 & 6.5 & 4.0 & $>8.0$ \\
\hline 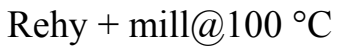 & 192 & 7.7 & 5.8 & 3.2 \\
\hline Rehy+mill@-79 ${ }^{\circ} \mathrm{C}$ & 193 & 7.7 & 5.8 & 2.5 \\
\hline Mill-rehy@150 ㄷ & 198 & 7.9 & 5.7 & 4.7 \\
\hline Mill-rehy@RT & 174 & 4.7 & - & - \\
\hline
\end{tabular}

The peak temperature of hydrogen desorption of the synthesized sample was located at $190{ }^{\circ} \mathrm{C}$. After the rehydrogenation without milling treatment, the peak was significantly shifted, to a temperature higher than $200{ }^{\circ} \mathrm{C}$. Moreover, it was noted that the weight loss was only 6.5 mass $\%$. The decrease in hydrogen capacity for the sample rehydrogenated by the only thermochemical reaction is, possibly, caused by the following reasons. During the heating processes for de/rehydrogenation, the crystalline size of solid materials is increased by sintering, resulting in the longer diffusion distance of atoms and the poor contact between the generated hydride and amide. In this case, the unreacted parts should remain after the TG-MS measurement. As another possibility, it seemed that the rehydrogenation was not completed under the conditions. Because both the rehy + mill samples revealed better hydrogen desorption properties, where the MS and TG profiles were almost same as those of the synthesized sample, the additional milling processes under $\mathrm{H}_{2}$ pressure is able to recover the close contact of both materials due to the reduction of crystalline size. 
The above results indicate that the small crystalline sizes should be preserved to prevent the decay of the essential hydrogen desorption properties. Thus, the rehydrogenation was performed by the mechanochemical reaction using ball-milling under $\mathrm{H}_{2}$ pressure, where the mechanochemically rehydrogenated samples are named "mill-rehy". The dehydrogenated sample was milled under two conditions: room temperature under $6.0 \mathrm{MPa}$ of $\mathrm{H}_{2}$ and $150{ }^{\circ} \mathrm{C}$ under $15.0 \mathrm{MPa}$ of $\mathrm{H}_{2}$ for $5 \mathrm{~h}$. At $150{ }^{\circ} \mathrm{C}$, the high pressure was applied to thermodynamically suppress the hydrogen desorption. The TG-MS profiles of mill-rehy@RT and mill-rehy@150 ${ }^{\circ} \mathrm{C}$ are shown in Figure 6.

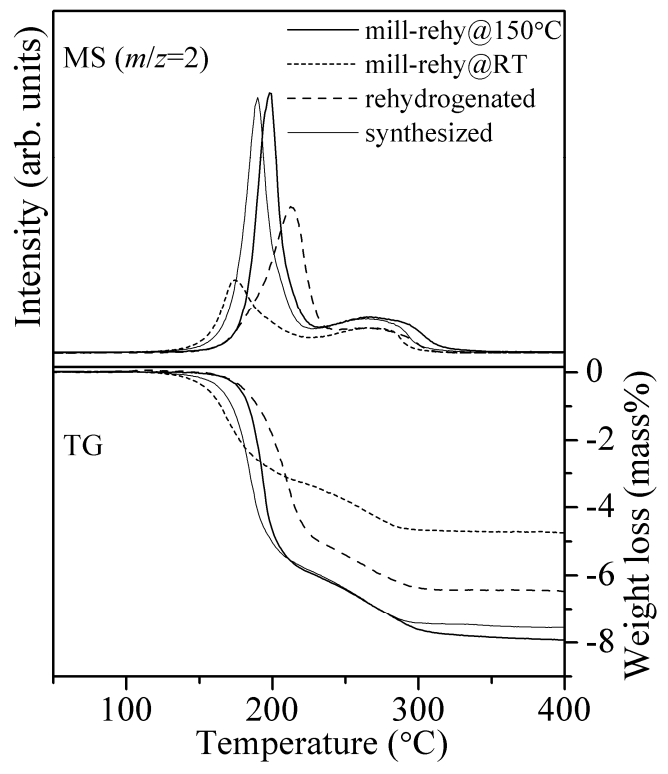

Figure 6. TG-MS profiles of the $8 \mathrm{LiH}-3 \mathrm{Mg}\left(\mathrm{NH}_{2}\right)_{2}$ samples after synthesis, thermochemical rehydrogenation, and mechanochemical rehydrogenation at room temperature and $150{ }^{\circ} \mathrm{C}$.

Figure 7 shows XRD patterns of $8 \mathrm{LiH}-3 \mathrm{Mg}\left(\mathrm{NH}_{2}\right)_{2}$ sample for all the processes. As already described above, the synthesized sample included the low crystalline $\mathrm{LiH}$ and $\mathrm{Mg}\left(\mathrm{NH}_{2}\right)_{2}$. After the dehydrogenation at $200{ }^{\circ} \mathrm{C}$, the diffraction peaks were still broad shape and would be originated in the similar structure to $\mathrm{Li}_{2} \mathrm{NH}$ and/or $\mathrm{LiMgN}$, which should be dehydrogenated state defined as $\mathrm{Li}_{1+x} \mathrm{MgN}_{2} \mathrm{H}_{3}-x$. In the XRD pattern of the thermochemical rehydrogenated sample, the sharp peaks corresponding to $\mathrm{LiH}$ and $\mathrm{Mg}\left(\mathrm{NH}_{2}\right)_{2}$ phases were clearly observed, suggesting that the crystallization of them proceeded during the rehydrogenation. Because the peaks assigned to the dehydrogenated phases completely disappeared, the poor hydrogen desorption properties of the rehydrogenated sample observed in the TG-MS measurement would be caused by the formation of worse mixing state between both materials due to the thermal crystallization. By the ball-milling at $100{ }^{\circ} \mathrm{C}$ and $-79{ }^{\circ} \mathrm{C}$ after the thermochemical rehydrogenation, $\mathrm{Mg}\left(\mathrm{NH}_{2}\right)_{2}$ was changed to nano-structural or amorphous phase. The shapes of peaks corresponding to $\mathrm{LiH}$ were similar to those of the synthesized sample. From these results, it is indicated that the low crystalline size are recovered. In fact, the hydrogen desorption properties was improved by the milling processes as shown in Figure 5. In the XRD pattern of mill-rehy@RT, the dehydrogenated phases remained although the crystalline $\mathrm{Mg}\left(\mathrm{NH}_{2}\right)_{2}$ was not observed. This result is consistent with the low hydrogen desorption capacity observed in the TG-MS measurement. After the mechanochemical rehydrogenation at $150{ }^{\circ} \mathrm{C}$, the XRD pattern was similar to the synthesized and rehy + mill samples. 


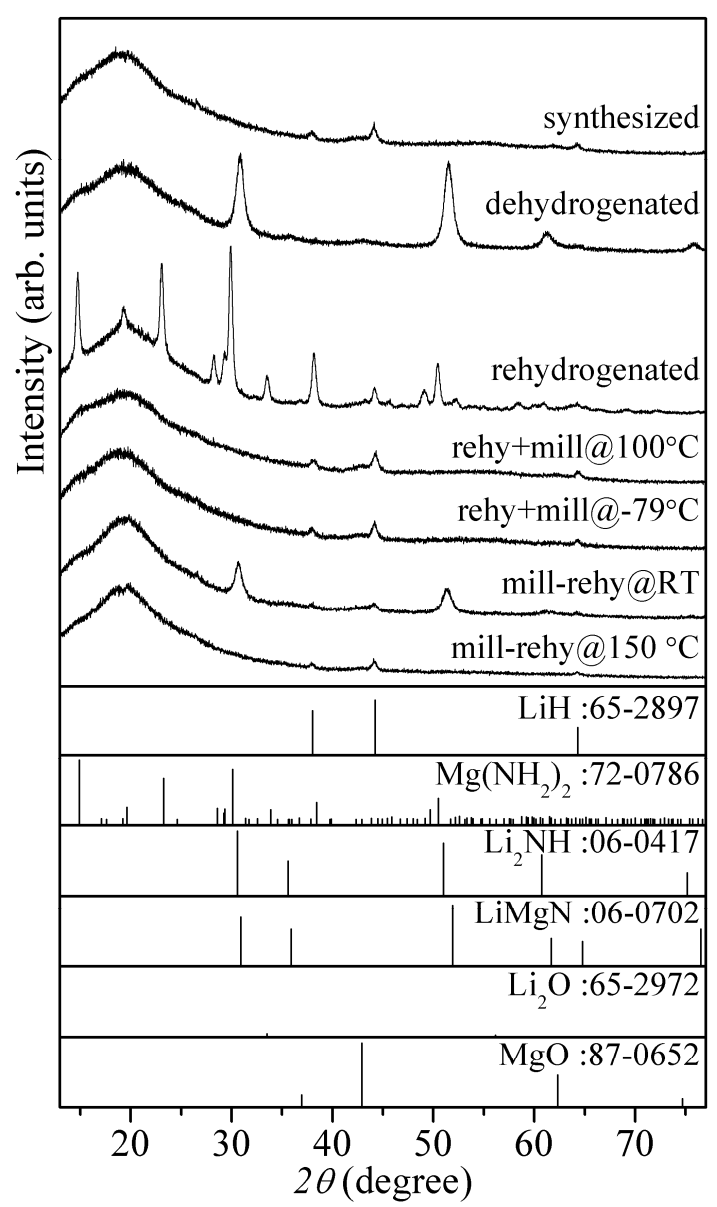

Figure 7. $\mathrm{XRD}$ patterns of the $8 \mathrm{LiH}-3 \mathrm{Mg}\left(\mathrm{NH}_{2}\right)_{2}$ samples after the synthesis, dehydrogenation, and various rehydrogenation processes. XRD patterns of $\mathrm{LiH}, \mathrm{Mg}\left(\mathrm{NH}_{2}\right)_{2}$, $\mathrm{Li}_{2} \mathrm{NH}, \mathrm{LiMgN}, \mathrm{Li}_{2} \mathrm{O}$, and $\mathrm{MgO}$ in database are shown as reference.

For the samples having better hydrogenated states, rehy + mill@100 ${ }^{\circ} \mathrm{C}$, rehy + mill@ $-79{ }^{\circ} \mathrm{C}$, and mill-rehy@150 ${ }^{\circ} \mathrm{C}$, the isothermal TG measurements were performed at $150{ }^{\circ} \mathrm{C}$. The obtained results are shown in Figure 8 with the results of synthesized and rehydrogenated samples. Furthermore, the weight loss observed for $8 \mathrm{~h}$ and the time required to desorb 5.5 mass $\%$ of $\mathrm{H}_{2}$, which is the target value of hydrogen capacity, are listed in Table 1 . The synthesized sample showed the fastest reaction rate, and about 5.5 mass \% of $\mathrm{H}_{2}$ can be desorbed within $1.8 \mathrm{~h}$. However, the hydrogen desorption of the thermochemically rehydrogenated sample was only 4.0 mass $\%$, even after reaction for $8 \mathrm{~h}$. The TG profiles of the rehy + mill samples were similar to each other and revealed relatively faster hydrogen desorption. As a result, 5.5 mass \% of $\mathrm{H}_{2}$ was obtained within $3.2 \mathrm{~h}$. Although the reaction rate of the mechanochemically rehydrogenated sample was slightly slower, the hydrogen desorption amount can reach 5.5 mass $\%$ after $4.7 \mathrm{~h}$. The difference between the rehy + mill and mill-rehy samples might be caused by the temperature of the rehydrogenation processes, namely, $150{ }^{\circ} \mathrm{C}$ might be too high to realize the suitable crystalline size and mixing state by competing with the thermal crystallization. By further optimizing the treatment conditions, the hydrogen desorption properties of mechanochemically rehydrogenated sample would be improved. 


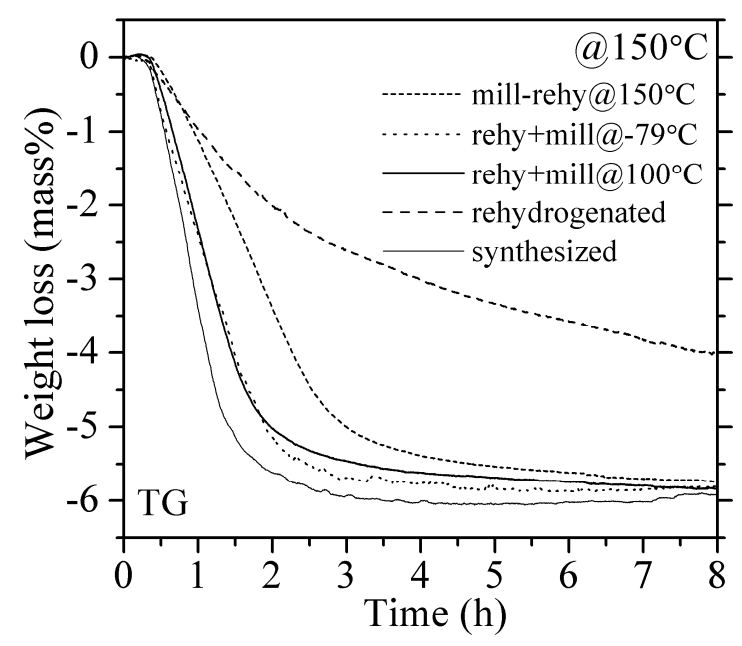

Figure 8. Isothermal TG profiles at $150^{\circ} \mathrm{C}$ of the $8 \mathrm{LiH}-3 \mathrm{Mg}\left(\mathrm{NH}_{2}\right)_{2}$ samples after the synthesis, and various rehydrogenation processes.

All the rehydrogenated samples showed about 5.8 mass $\%$ for $8 \mathrm{~h}$, although the initial reaction rate was different for each sample, and then the reaction stage should be in the non-stoichiometric variation and roughly described as follows:

$$
\begin{aligned}
& 8 \mathrm{LiH}+3 \mathrm{Mg}\left(\mathrm{NH}_{2}\right)_{2} \rightarrow 3 \mathrm{Li}_{2.2} \mathrm{MgN}_{2} \mathrm{H}_{1.8}+1.6 \mathrm{LiH}+6.4 \mathrm{H}_{2}(5.5 \text { mass } \%) \\
& 8 \mathrm{LiH}+3 \mathrm{Mg}\left(\mathrm{NH}_{2}\right)_{2} \rightarrow 3 \mathrm{Li}_{2.3} \mathrm{MgN}_{2} \mathrm{H}_{1.7}+1.3 \mathrm{LiH}+6.7 \mathrm{H}_{2}(5.8 \text { mass\% })
\end{aligned}
$$

from the above experimental results, it is clarified that the crystalline size and contact between $\mathrm{LiH}$ and $\mathrm{Mg}\left(\mathrm{NH}_{2}\right)_{2}$ are important factors to realize the suitable reaction kinetics. Furthermore, it is demonstrated that the $8 \mathrm{LiH}-3 \mathrm{Mg}\left(\mathrm{NH}_{2}\right)_{2}$ system is the potential hydrogen storage material to achieve 5.5 mass $\%$ of $\mathrm{H}_{2}$ desorption at $150{ }^{\circ} \mathrm{C}$, even after the rehydrogenation by preserving the suitable crystalline size and mixing state. The reaction mechanism was proposed in previous literature, reported by Isobe et al. [20] and Nakamura et al. [23]. In the hydrogen desorption Reaction (5), $\mathrm{H}^{+}$in the non-stoichiometric $\mathrm{Li}_{1+x} \mathrm{MgN}_{2} \mathrm{H}_{3-x}$ phase and $\mathrm{Li}^{+}$in $\mathrm{LiH}$ are diffused and exchanged each other via thorough the interface between the solid phases, and then Li-rich/H-poor imide phase are generated. The $\mathrm{H}_{2}$ desorption proceeds by combining $\mathrm{H}^{+}$diffused from $\mathrm{Li}_{1+x} \mathrm{MgN}_{2} \mathrm{H}_{3-x}$ with $\mathrm{H}^{-}$in $\mathrm{LiH}$. This proposed mechanism is quite reasonable from the points of view of charge and mass balance in the system. Considering the above hydrogen desorption mechanism, it is expected that the shorter diffusion distance of the ions and the larger number of interface between both materials will realize the fast hydrogen desorption. Therefore, the experimental facts in this work strongly support the reaction mechanism.

\section{Experimental Section}

Commercial LiH (99.4\%, Alfa Aesar, Lancashire, UK) was used as the starting material. $\mathrm{Mg}\left(\mathrm{NH}_{2}\right)_{2}$ was synthesized by ball-milling $\mathrm{MgH}_{2}$ (95\%, Gelest Inc., Morrisville, PA, USA) under 0.6 $\mathrm{MPa}$ of $\mathrm{NH}_{3}$, where the ball-milling was performed at room temperature by using a planetary ball-mill apparatus (P5, Fritsch, Idar-Oberstein, Germany) with $250 \mathrm{rpm}$ for $10 \mathrm{~h}$. The purity of synthesized $\mathrm{Mg}\left(\mathrm{NH}_{2}\right)_{2}$ was evaluated by the weight loss with thermal decomposition ( $\mathrm{NH}_{3}$ desorption) to $500{ }^{\circ} \mathrm{C}$ and estimated to be about $95 \%$. Here, the synthesized $\mathrm{Mg}\left(\mathrm{NH}_{2}\right)_{2}$ possesses low crystallinity like nano-structural or 
amorphous phase because the crystalline size is decreased by the mechanical energy applied during the ball-milling process. To know the effect of starting crystalline size, $\mathrm{LiH}$ was pre-treated by the ball-milling (P7, Fritsch, Idar-Oberstein, Germany) under $1.0 \mathrm{MPa}$ of $\mathrm{H}_{2}$ for $10 \mathrm{~h}$ and $34 \mathrm{~h}$. The pristine or milled $\mathrm{LiH}$ was mixed with $\mathrm{Mg}\left(\mathrm{NH}_{2}\right)_{2}$ by the ball-milling under $1.0 \mathrm{MPa}$ of $\mathrm{H}_{2}$ for 2,20 , and $40 \mathrm{~h}$, where the molar ratio of $\mathrm{Li}$ and $\mathrm{Mg}$ was 8:3 (73:27 mol\%). In addition, the catalyzed samples were also prepared, in which $0.54 \mathrm{~mol} \% \mathrm{TiCl}_{3}(98 \%)$ was added into the above mixing process for $20 \mathrm{~h}$. The amount of $\mathrm{TiCl}_{3}$ was chosen to be $2 \mathrm{~mol} \%$ for $\mathrm{Mg}\left(\mathrm{NH}_{2}\right)_{2}$ based on previous reports for the $\mathrm{LiH}_{-\mathrm{LiNH}_{2}}$ system [27,29]. For all the ball-milling process, $30 \mathrm{~min}$ interval is taken into every $1 \mathrm{~h}$ milling. The dehydrogenation of the samples was carried out at $200^{\circ} \mathrm{C}$ for $24 \mathrm{~h}$ under dynamic vacuum condition. For the rehydrogenation, various procedures were performed as follows (see Figure S1). As the conventional thermochemical rehydrogenation, the dehydrogenated sample was heat-treated at $200{ }^{\circ} \mathrm{C}$ for $12 \mathrm{~h}$ under $10.0 \mathrm{MPa}$ of $\mathrm{H}_{2}$. In addition, the rehydrogenated samples were ball-milled at room temperature under $1 \mathrm{MPa}$ of $\mathrm{H}_{2}$ for $20 \mathrm{~h}$, at $100{ }^{\circ} \mathrm{C}$ under $10 \mathrm{MPa}$ of $\mathrm{H}_{2}$ for $5 \mathrm{~h}$, and at $-79{ }^{\circ} \mathrm{C}$ under $1 \mathrm{MPa}$ of $\mathrm{H}_{2}$ for $2 \mathrm{~h}$, where the products were named rehy + mill@RT, rehy + mill@ $100{ }^{\circ} \mathrm{C}$, and rehy+ mill@ $-79{ }^{\circ} \mathrm{C}$, respectively. For the ball-milling at $-79{ }^{\circ} \mathrm{C}$, the milling pot was cooled by the jacket filled with dry ice. Furthermore, the rehydrogenation was performed by the mechanochemical reaction. The dehydrogenated sample was milled at room temperature under $6.0 \mathrm{MPa}$ of $\mathrm{H}_{2}$ for $5 \mathrm{~h}$ by a vibrating ball-mill apparatus (RM-10, Seiwa Giken, Hiroshima, Japan) and at $150{ }^{\circ} \mathrm{C}$ under $15.0 \mathrm{MPa}$ of $\mathrm{H}_{2}$ for $5 \mathrm{~h}$ by a high-pressure type of vibrating ball-mill apparatus (RM-40, Seiwa Giken, Hiroshima, Japan). These rehydrogenated samples are named mill-rehy@RT and mill-rehy@150 ${ }^{\circ} \mathrm{C}$. All the sample treatment was performed in a glove box filled with purified Ar (MP-P60W, Miwa MFG, Ibaraki, Osaka, Japan) because the $\mathrm{Li}$ and $\mathrm{Mg}$ compounds are easily oxidized in the air.

To identify the solid materials and discuss the structural properties, X-ray diffraction (XRD) measurement (RINT-2100, CuK $\alpha$ radiation, Rigaku, Akishima, Japan) was performed, where the samples were covered by a polyimide sheet (Kapton ${ }^{\circledR}$, Du Pont-Toray Co., Ltd., Chuo-ku, Tokyo, Japan) to avoid sample oxidation. The hydrogen desorption properties were evaluated by thermogravimetry (TG, TG8120, Rigaku, Akishima, Japan) and mass spectroscopy (MS, M-QA200TS, Anelva, Kawasaki, Japan), which are placed into a glove box to measure essential properties of the samples without the influence of oxidation. For the TG-MS measurements, He gas was flowed as a carrier gas, suggesting that the $\mathrm{H}_{2}$ partial pressure around the sample would be kept to low level. The heating rate was fixed to be $5{ }^{\circ} \mathrm{C} \cdot \mathrm{min}^{-1}$. To evaluate the reaction rate and determine the utilizable hydrogen amount at $150{ }^{\circ} \mathrm{C}$, an isothermal TG experiment was carried out, where the heating rate from room temperature to $150{ }^{\circ} \mathrm{C}$ was $5{ }^{\circ} \mathrm{C} \cdot \mathrm{min}^{-1}$ and the total measurement time was $8 \mathrm{~h}$.

\section{Conclusions}

In this work, the synthesis and rehydrogenation processes of the $8 \mathrm{LiH}-3 \mathrm{Mg}\left(\mathrm{NH}_{2}\right)_{2}$ system were investigated to achieve the target properties, 5.5 mass $\%$ of hydrogen storage capacity and $150{ }^{\circ} \mathrm{C}$ of operating temperature.

For the synthesis, the effects of pre-milling for $\mathrm{LiH}$, milling time of mixing $\mathrm{LiH}$ with $\mathrm{Mg}\left(\mathrm{NH}_{2}\right)_{2}$, and $\mathrm{TiCl}_{3}$ catalyst were examined. The pre-treatment decreased the crystalline size of $\mathrm{LiH}$ and improved the hydrogen desorption properties of the $2 \mathrm{~h}$ milled $8 \mathrm{LiH}-3 \mathrm{Mg}\left(\mathrm{NH}_{2}\right)_{2}$ sample. However, the $8 \mathrm{LiH}-3 \mathrm{Mg}\left(\mathrm{NH}_{2}\right)_{2}$ 
samples milled for more than $20 \mathrm{~h}$ was not improved by the pre-treatment of $\mathrm{LiH}$. In this case, the effect of pre-treatment of $\mathrm{LiH}$ was negligible. $\mathrm{TiCl}_{3}$ revealed no catalytic effect for the $8 \mathrm{LiH}-3 \mathrm{Mg}\left(\mathrm{NH}_{2}\right)_{2}$ system although it was effective for the $\mathrm{LiH}-\mathrm{LiNH}_{2}$ system. Thus, the crystalline size and mixing state are important factors to realize the fast hydrogen desorption properties.

For the rehydrogenation, the thermochemical and mechanochemical processes were investigated. After the only thermochemical rehydrogenation, the reaction rate of hydrogen desorption was clearly slowed due to the crystallization, which might be caused by the poor contact of the regenerated $\mathrm{LiH}$ and $\mathrm{Mg}\left(\mathrm{NH}_{2}\right)_{2}$. The ball-milling process for the rehydrogenated sample can recover the low crystalline size and showed fast hydrogen desorption. The mechanochemical rehydrogenation by ball-milling the dehydrogenated sample under $\mathrm{H}_{2}$ atmosphere was also useful because the hydrogen desorption properties of the obtained sample were almost the same as the synthesized sample, where the higher temperature of more than $150{ }^{\circ} \mathrm{C}$ was required to complete the hydrogen absorption. The rehydrogenated samples, which were obtained by the thermochemical rehydrogenation plus ball-milling and mechanochemical rehydrogenation, can desorb more than 5.5 mass $\%$ of $\mathrm{H}_{2}$ at $150{ }^{\circ} \mathrm{C}$.

From the experimental facts obtained in this work, it is demonstrated that the $8 \mathrm{LiH}-3 \mathrm{Mg}\left(\mathrm{NH}_{2}\right)_{2}$ system can be considered a potential hydrogen storage materials to achieve the NEDO target by preserving the suitable crystalline size and contact state of $\mathrm{LiH}$ and $\mathrm{Mg}\left(\mathrm{NH}_{2}\right)_{2}$. Here, since a mechanical process, such as ball-milling, might not be useful as a practical application, other moderate techniques to prevent crystallization and isolation should be developed ideally. In addition, the reaction rate of the system is still slow for practical use, suggesting that further improvement is required in future works.

\section{Supplementary Materials}

Supplementary materials can be accessed at: http://www.mdpi.com/1996-1944/8/7/3896/s1.

\section{Acknowledgements}

The authors gratefully acknowledge Liang Zeng, Masami Tsubota and Tessui Nakagawa for their useful discussion and valuable help in this work. This work is partially supported by project "Development for Safe Utilization and Infrastructure of Hydrogen Industrial Technology" (P03015) of New Energy and Industrial Technology Development Organization (NEDO), Japan.

\section{Author Contributions}

All authors contributed to the experiments, analyses, and discussion of the article. Preparation of the manuscript was mainly carried out by Hiroki Miyaoka and Takayuki Ichikawa. The experiments were performed by mainly Yongming Wang and supported by Satoshi Hino, Shigehito Isobe, Kazuhiko Tokoyoda, and Hiroki Miyaoka. Yoshitsugu Kojima gave the important suggestion for discussion about the experimental results. All authors have given approval of the final version to be submitted.

\section{Conflicts of Interest}

The authors declare no conflict of interest. 


\section{References}

1. New Energy and Industrial Technology Development Organization. Available online: http://www.nedo.go.jp (accessed on 18 June 2015).

2. Orimo, S.; Majer, G.; Fukunaga, T.; Züttel, A.; Schlapbach, L.; Fujii, H. Hydrogen in the mechanically prepared nanostructured graphite. Appl. Phys. Lett. 1999, 75, 3093-3095.

3. Orimo, S.; Nakamori, Y.; Eliseo, J.R.; Zuttel, A.; Jensen, C.M. Complex hydrides for hydrogen storage. Chem. Rev. 2007, 107, 4111-4132.

4. Sakintuna, B.; Lamari-Darkrim, F.; Hirscher, M. Metal hydride materials for solid hydrogen storage: A review. Int. J. Hydrog. Energy 2007, 32, 1121-1140.

5. Chen, P.; Zhu, M. Recent progress in hydrogen storage. Mater. Today 2008, 11, 36-43.

6. Smith, C.I.; Miyaoka, H.; Ichikawa, T.; Jones, M.O.; Harmer, J.; Ishida, W.; Edwards, P.P.; Kojima, Y.; Fujii, H. Electron Spin Resonance Investigation of Hydrogen Absorption in Ball-Milled Graphite. J. Phys. Chem. C 2009, 113, 5409-5416.

7. Miyaoka, H.; Ichikawa, T.; Kojima, Y. The reaction process of hydrogen absorption and desorption on the nanocomposite of hydrogenated graphite and lithium hydride. Nanotechnol. 2009, 20, 204021-204025.

8. Miyaoka, H.; Ichikawa, T.; Fujii, T.; Ishida, W.; Isobe, S.; Fujii, H.; Kojima, Y. Anomalous hydrogen absorption on non-stoichiometric iron-carbon compound. J. Alloy. Compd. 2010, 507, 547-550.

9. Liu, C.; Li, F.; Ma, L.P.; Cheng, H.M. Advanced Materials for Energy Storage. Adv. Mater. 2010, 22, E28-E62.

10. Yoshida, A.; Okuyama, T.; Mori, Y.; Saito, N.; Naito, S. Hydrogen Storage Material Composed of Polyacetylene and LiH and Investigation of Its Mechanisms. Chem. Mater. 2014, 26, 4076-4081.

11. Ward, P.A.; Teprovich, J.A., Jr.; Compton, R.N.; Schwartz, V.; Veith, G.M.; Zidan, R. Evaluation of the physi- and chemisorption of hydrogen in alkali (Na, Li) doped fullerenes. Int. J. Hydrog. Energy 2015, 40, 2710-2716.

12. Chen, P.; Xiong, Z.T.; Luo, J.Z.; Lin, J.Y.; Tan, K.L. Interaction of hydrogen with metal nitrides and imides. Nature 2002, 420, 302-304.

13. Kojima, Y.; Kawai, Y. IR characterizations of lithium imide and amide. J. Alloy. Compd. 2005, 395, 236-239.

14. Isobe, S.; Ichikawa, T.; Tokoyoda, K.; Hanada, N.; Leng, H.; Fujii, H.; Kojima, Y. Evaluation of enthalpy change due to hydrogen desorption for lithium amide/imide system by differential scanning calorimetry. Thermochim. Acta 2008, 468, 35-38.

15. Tokoyoda, K.; Ichikawa, T.; Miyaoka, H. Evaluation of the enthalpy change due to hydrogen desorption for $\mathrm{M}-\mathrm{N}-\mathrm{H}(\mathrm{M}=\mathrm{Li}, \mathrm{Mg}, \mathrm{Ca})$ systems by differential scanning calorimetry. Int. J. Hydrog. Energy 2015, 40, 1516-1522.

16. Luo, W. ( $\mathrm{LiNH}_{2}-\mathrm{MgH}_{2}$ ): A viable hydrogen storage system. J. Alloy. Compd., 2004, 381, 284-287.

17. Leng, H.Y.; Ichikawa, T.; Hino, S.; Hanada, N.; Isobe, S.; Fujii, H. New metal-N-H system composed of $\mathrm{Mg}\left(\mathrm{NH}_{2}\right)_{2}$ and $\mathrm{LiH}$ for hydrogen storage. J. Phys. Chem. B 2004, 108, 8763-8765.

18. Xiong, Z.; Wu, G.; Hu, J.; Chen, P. Ternary Imides for Hydrogen Storage. Adv. Mater. 2004, 16, $1522-1525$. 
19. Nakamori, Y.; Kitahara, G.; Miwa, K.; Towata, S.; Orimo, S. Reversible hydrogen-storage functions for mixtures of $\mathrm{Li}_{3} \mathrm{~N}$ and $\mathrm{Mg}_{3} \mathrm{~N}_{2}$. Appl. Phys. A Mater. Sci. Process. 2005, 80, 1-3.

20. Isobe, S.; Ichikawa, T.; Leng, H.; Fujii, H.; Kojima, Y. Hydrogen desorption processes in Li-Mg-N-H systems. J. Phys. Chem. Solids 2008, 69, 2234-2236.

21. Aoki, M.; Noritake, T.; Kitahara, G.; Nakamori, Y.; Towata, S.; Orimo, S. Dehydriding reaction of $\mathrm{Mg}\left(\mathrm{NH}_{2}\right)_{2}$-LiH system under hydrogen pressure. J. Alloy. Compd. 2007, 428, 307-311.

22. Ichikawa, T.; Tokoyoda, K.; Leng, H.Y.; Fujii, H. Hydrogen absorption properties of Li-Mg-N-H system. J. Alloy. Compd. 2005, 400, 245-248.

23. Nakamura, Y.; Hino, S.; Ichikawa, T.; Fujii, H.; Brinks, H.W.; Hauback, B.C. Dehydrogenation reaction of Li-Mg-N-H systems studied by in situ synchrotron powder X-ray diffraction and powder neutron diffraction. J. Alloy. Compd. 2008, 457, 362-367.

24. Ikeda, S.; Tokoyoda, K.; Kiyobayashi, T.; Kuriyama, N. Cyclic properties and ammonia by-product emission of Li/Mg-N-H hydrogen storage material. Int. J. Hydrog. Energy 2011, 36, 8373-8380.

25. Leng, H.Y.; Ichikawa, T.; Hino, S.; Hanada, N.; Isobe, S.; Fujii, H. Synthesis and decomposition reactions of metal amides in metal-N-H hydrogen storage system. J. Power Sources 2006, 156, $166-170$.

26. Leng, H.; Ichikawa, T.; Fujii, H. Hydrogen storage properties of Li-Mg-N-H systems with different ratios of $\mathrm{LiH} / \mathrm{Mg}\left(\mathrm{NH}_{2}\right)_{2}$. J. Phys. Chem. B 2006, 110, 12964-12968.

27. Ichikawa, T.; Isobe, S.; Hanada, N.; Fujii, H. Lithium nitride for reversible hydrogen storage. J. Alloy. Compd. 2004, 365, 271-276.

28. Matsumoto, M.; Haga, T.; Kawai, Y.; Kojima, Y. Hydrogen desorption reactions of Li-N-H hydrogen storage system: Estimation of activation free energy. J. Alloy. Compd. 2007, 439, 358-362.

29. Ichikawa, T.; Hanada, N.; Isobe, S.; Leng, H.Y.; Fujii, H. Hydrogen storage properties in Ti catalyzed Li-N-H system. J. Alloy. Compd. 2005, 404, 435-438.

(C) 2015 by the authors; licensee MDPI, Basel, Switzerland. This article is an open access article distributed under the terms and conditions of the Creative Commons Attribution license (http://creativecommons.org/licenses/by/4.0/). 